\title{
PENGARUH MOTIVASI DAN PELIMPAHAN WEWENANG SEBAGAI VARIABEL MODERATING DALAM HUBUNGAN ANTARA PARTISIPASI ANGGARAN DAN KINERJA MANAJERIAL (STUDI EMPIRIS PADA BEBERAPA PERUSAHAAN MANUFAKTUR DI SEMARANG)
}

\begin{abstract}
This research purpose is to test empirically the effect of budget participation on manager performance with motivation and responsibility chance as moderating variables. The Respondents of this research are manager, chief executive and supervisor of 6 manufactories corporate in Semarang city, where each manufacture corporate was gave fifteen (15) quesioner directly. Samples was choosed with criterias manager, sub-leader, and supervisors who activaly involve with budget setter and performance evaluation. These results of research suggest that first, budget participation have effect directly on manager performance, second budget participation have effect indirectly on manager performance via motivation and third responsibility chance as moderating variables on the effect budget participation on manager performance.
\end{abstract}

Keyword: motivation, responsibility chance, budget performance and manager participation

\section{PENDAHULUAN}

Anggaran merupakan salah satu komponen penting dalam perencanaan perusahaan, yang berisikan rencana kegiatan dimasa depan dan mengindikasikan kegiatan untuk mencapai tujuan tersebut (Hansen dan Mowen 2000, dalam Marani dan Supomo 2003). Anggaran koordinasi, komunikasi, evaluasi kerja dan motivasi (Cherrington 1973, Schiff dan Lewis 1970, Kennis 1979, Chow dkk 1988) serta alat untuk mendelegasikan wewenang atasan kepada bawahan (Hofstede 1968 dalam Marani dan Supomo 2003).

Proses penyusunan anggaran suatu organisasi merupakan kegiatan yang penting sekaligus kompleks, karena anggaran mempunyai kemungkinan dampak fungsional atau disfungsional terhadap sikap dan perilaku anggota organisasi (Argyris 1952, Milani 1975 dalam Binti dan Suryanto 2002). Menurut Argyris (1952) dalam Binti dan Suryanto (2002:127), anggaran yang disusun terlalu kaku dengan target yang terlalu sulit dicapai, justru tidak memotivasi bawahan untuk meningkatkan kinerjanya dan bahkan menyebabkan tidak efisien.

Motivasi dan pelimpahan wewenang sebagai variabel moderating perlu di evaluasi kembali sebagai faktor moderating terhadap hubungan antara partisipasi penyusunan anggaran dengan kinerja manajerial. Untuk mengetahui apakah motivasi berperan sebagai variabel moderating, dapat dilihat pada motivasi para manajer yang berpartisipasi dalam penyusunan anggaran (Marani dan Supomo 2003). Dalam proses penyusunan anggaran, akan lebih efektif dilakukan pada kondisi karyawan yang mempunyai motivasi yang tinggi, begitu juga sebaliknya (Mia 1988 dalam Marani dan Supomo 2003).

Pelimpahan wewenang adalah pemberian wewenang oleh manajer yang lebih tinggi kepada manajer yang lebih rendah untuk melaksanakan suatu pekerjaan dengan otorisasi secara eksplisit dari manajer pemberi wewenang pada waktu wewenang tersebut dilaksanakan (Mulyadi dan Setyawan 2000 dalam 
Marani dan Supomo 2003). Menurut Bruns dan Waterhouse (1975) dalam Marani dan Supomo (2003), manajer dalam organisasi yang tingkat desentralisasinya tinggi merasa dirinya orang yang lebih berpengaruh, lebih berpartisipasi dalam perencanaan anggaran, dan merasa dipuaskan dengan kegiatan yang berhubungan dengan anggaran demikian pula sebaliknya.

Kinerja manajerial yang dimaksud dalam penelitian ini adalah kinerja manajerial dalam kegiatan-kegiatan manajerial yang meliputi perencanaan, investigasi, pengkoordinasian, evaluasi, pengawasan, pengaturan staf (staffing) dan perwakilan atau representative (Mahoney et al 1963 dalam Riyadi 2000:135).

MenurutKenis (1979) dalamWijayanti dan Solichatun (2005) partisipasi penyusunan anggaran didefinisikan sebagai keterlibatan manajer dalam menyusun anggaran tersebut pada pusat pertanggungjawaban manajer yang bersangkutan. Hubungan antara partisipasi dalam proses penyusunan anggaran dengan kinerja manajerial telah banyak di kaji dan terdapat beberapa perdebatan, sehingga menarik minat para peneliti untuk melakukan penelitian lebih lanjut terhadap hubungan tersebut (Argyris 1952, Milani 1975, Kenis 1979, Brownell 1981, 1982b, Brownell dan McInnes 1986, dan Birnberg et al 1990 dalam Riyadi 2000:135). Hasil penelitian yang telah dilakukan oleh Bass dan Leavitt (1963); Schuler dan Kim (1976); Brownell (1982b); Brownell dan Mclnnes (1986); dan Indriantoro (1993) menemukan bahwa ada hubungan positif dan signifikan antara partisipasi penyusunan anggaran dengan kinerja manajerial. Sementara hasil penelitian Milani (1975); Kenis (1979); dan Riyanto (1996) menunjukkan bahwa terdapat hubungan yang tidak signifikan diantara keduanya, sedangkan beberapa penelitian yang lain melaporkan bahwa hubungan kedua variabel tersebut bertolak belakang atau negatif (Sterdy 1960, Bryan dan Locke 1967) dalam Riyadi (2000).

Penelitian yang menguji hubungan antara kedua variabel tersebut menunjukkan hasil yang tidak konsisten. Untuk merekonsiliasi temuan penelitian yang bertentangan tersebut, perlu digunakan pendekatan kontijensi dan upaya untuk mengidentifikasi berbagai kondisi yang menyebabkan anggaran partisipatif menjadi efektif (Govindarajan 1986 dalam Supomo dan Indriantoro 1998).

\section{TELAAH LITERATUR DAN PENGEMBANGAN HIPOTESIS}

\section{Partisipasi Anggaran}

Partisipasi dalam proses penyusunan anggaran merupakan pendekatan yang efektif untuk meningkatkan motivasi manajer. Dengan tingkat partisipasi yang tinggi cenderung mendorong manajer untuk lebih aktif didalam memahami anggaran (Anthony dan Govindarajan 1995 dalam Marani dan Supomo 2003:49), dan manajer akan memiliki pemahaman yang baik dalam menghadapi kesulitan pada saat pelaksanaan anggaran. Anggaran yang efektif berhasil harus melibatkan bawahan dalam tanggungjawab pengendalian biaya untuk membuat etimasi anggaran.

Partisipasi penyusunan anggaran didefinisikan sebagai keterlibatan manajer dalam menyusun anggaran tersebut pada saat pertanggungjawaban manajer yang bersangkutan (Kenis 1979 dalam Wijayanti dan Solichatun 2005:186). Partisipasi dalam pembuatan anggaran berkaitan dengan seberapa jauh keterlibatan pimpinan atau kepala bagian organisasi dalam penentuan atau penyusunan anggaran pada bagian atau unit organisasinya (Pratolo 2003:19). 
Menurut Milani (1975) dalam Marani dan Supomo (2003:49), tingkat keterlibatan dan pengaruh manajer dalam proses penyusunan anggaran merupakan kondisi yang membedakan antara anggaran partisipatif dan anggaran non partisipatif. Mia (1988) dalam Marani dan Supomo (2003:49) menyimpulkan bahwa sistem anggaran (partisipatif atau non partisipatif) yang sesuai dengan sikap dan motivasi yang dimiliki anggota organisasi menentukan baik buruknya suatu organisasi.

Menurut Anthony dan Govindarajan (1995) dalam Wijayanti (2005:186), tingkat partisipasi yang tinggi cenderung mendorong manajer untuk lebih aktif di dalam memahami anggaran. Dengan pemahaman yang baik, manajer diharapkan akan dapat melaksanakan anggaran sesuai yang ditargetkan serta dapat menghadapi kesulitan pada saat pelaksanaan anggaran.

\section{Kinerja Manajerial}

Kinerja manajerial merupakan salah satu faktor yang dapat meningkatkan efektivitas organisasi. Menurut Mahoney dkk (1993) dalam Marani dan Supomo (2003:50) kinerja manajerial adalah kinerja para individu anggota organisasi dalam kegiatan-kegiatan manajerial, seperti perencanaan, investigasi, koordinasi, pengaturan staf, negosiasi dan representasi. Penilaian kinerja ini dilakukan untuk menekan perilaku yang tidak semestinya dan untuk memotivasi manusia disuatu organisasi agar berjalan dengan semestinya.

\section{Konsep Pendekatan Kontijensi}

Pendekatan kontinjensi memungkinkan variabel-variabel lain yang bertindak sebagai faktor moderating atau intervening yang mempengaruhi hubungan antara partisipasi penyusunan anggaran dengan kinerja manajerial (Brownell 1982a dalam Riyadi 2000:137). Menurut Murray (1990) dalam Riyadi (2000:137), faktor moderating adalah faktor atau variabel yang mempengaruhi hubungan antara dua variabel. Faktor kontinjensi dalam penelitian ini adalah motivasi kerja yang dimiliki manajer untuk variabel psikologi (Mia 1988), sedangkan untuk faktor kontekstual organisasional adalah pelimpahan wewenang yang diberikan perusahaan kepada manajer (Gul et al 1995 dalam Marani dan Supomo 2003:50).

\section{HIPOTESIS}

Hipotesis dalam penelitian ini adalah :

H1 : Partisipasi anggaran berpengaruh secara signifikan terhadap kinerja manajerial.

H2: Partisipasi anggaran berpengaruh secara signifikan terhadap kinerja manjerial dengan variabel moderating motivasi kerja.

H3: Partisipasi anggaran berpengaruh secara signifikan terhadap kinerja manajerial dengan variabel moderating pelimpahan wewenang.

\section{METODE PENELITIAN}

Populasi dalam penelitian ini adalah perusahaan yang bergerak dalam bidang manufaktur. Diperoleh data dari 6 (enam) perusahaan manufaktur di Semarang, dimana setiap perusahaan manufaktur yang ada disebarkan 15 kuesioner secara langsung. Kriteria sampel pada penelitian ini adalah setingkat manajer yang terdiri dari manajer, kepala bagian dan supervisor yang biasanya terlibat aktif dalam penyusunan anggaran 
dan penilaian kinerja.

Variabel bebas (Independen) dalam penelitian ini yaitu partisipasi anggaran. Dalam pengukuran partisipasi anggaran digunakan instrumen dari Milani (1975) dan diadopsi oleh Kren (1992) dalam Wijayanti dan Solichatun (2005), ada enam item untuk mengukur partisipasi yang terbagi dalam tiga dimensi, yaitu : Sejauh mana ide manajer mempengaruhi keputusan, Seberapa besar pertimbangan manajer dipakai dalam penentuan anggaran, Seberapa sering atasan meminta pertimbangan bawahan.

Variabel motivasi dimaksudkan untuk mengetahui motivasi apa yang mendorong seorang manajer untuk melakukan pekerjaannya dengan baik. Instrumen ini terdiri dari 23 (dua puluh tiga) pertanyaan yang terbagi dalam tiga dimensi, yaitu (Wijayanti dan Solichatun 2005:189): a. Untuk mengetahui bagaimana kemungkinan pemberian kompensasi atas kerja keras yang dilakukan. b. Untuk mengukur seberapa penting kompensasi yang diterima atas produktivitas yang tinggi, kesempatan yang dapat diperoleh atas pekerjaan yang telah dilaksanakan dengan baik, serta kinerja yang baik, c. Untuk megetahui seberapa sering faktor pertama (bekerja keras) mengarah pada faktor kedua (produktivitas tinggi, mengerjakan pekerjaan dengan baik, dan kinerja yang baik).

Pelimpahan Wewenang diukur dengan menggunakan instrumen yang dikembangkan oleh Gordon dan Narayana (1984) dalam Marani dan Supomo (2003:54). Ada lima item instrumen yang diminta oleh manajer untuk menunjukkan wewenang yang mereka miliki dalam lima keputusan operasional penting yang dapat mempengaruhi kinerja mereka.

Variabel terikat dalam penelitian ini adalah kinerja manajerial. Pengukuran variabel kinerja menggunakan instrumen selfrating (manajer diminta menilai sendiri kinerjanya) yang dikembangkan oleh Mahoney dkk (1965) dan instrumen ini juga digunakan oleh kren (1992) dalam Wijayanti dan Solichatun (2005:189). Instrumen ini mengukur kinerja seorang manajer yang terdiri dari sembilan pertanyaan yang terbagi dalam tujuh dimensi yaitu perencanaan, koordinasi, evaluasi, supervisi, pengaturan staf (staffing), negosiasi, dan representasi.

Persamaan regresi digunakan untuk menguji hipotesa adalah :

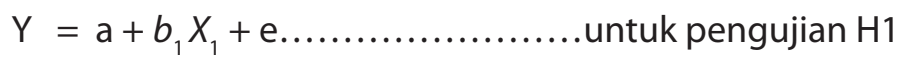

$$
\begin{aligned}
& \mathrm{Y}=\mathrm{a}+b_{1} X_{1}+b_{2} X_{2}+b_{3} X_{1} X_{2}+\text { e..........untuk pengujian } \mathrm{H} 2 \\
& \mathrm{Y}=\mathrm{a}+b_{1} X_{1}+b_{4} X_{3}+b_{5} X_{1} X_{3}+\text { e.........untuk pengujian } \mathrm{H} 3
\end{aligned}
$$

Dimana:

$$
\begin{array}{ll}
\mathrm{Y} & =\text { Kinerja manajerial } \\
\mathrm{X}_{1} & =\text { Partisipasi anggaran } \\
\mathrm{X}_{2} & =\text { Motivasi } \\
\mathrm{X}_{3} & =\text { Pelimpahan wewenang } \\
\mathrm{X}_{1} \mathrm{X}_{2} & =\text { Interaksi antara partisipasi anggaran dan motivasi } \\
\mathrm{X}_{1} \mathrm{X}_{3} & =\text { Interaksi antara partisipasi anggaran dan pelimpahan wewenang } \\
\mathrm{a} & =\text { Konstanta } \\
\mathrm{b} & =\text { Koefisien regresi } \\
\mathrm{e} & =\text { Error }
\end{array}
$$




\section{HASIL DAN PEMBAHASAN}

\section{Pengujian Hipotesis Pertama}

Hasil pengujian Hipotesis pertama mengenai pengaruh partisipasi anggaran terhadap kinerja manajerial menunjukkan nilai t sebsar 4,860 dengan signifikansi sebesar 0,000. Hal ini berarti bahwa partisipasi anggaran berpengaruh signifikan terhadap kinerja manajerial. Hal ini berarti Hipotesis pertama diterima. Nilai koefisien determinasi (R square) dari model regresi pertama diperoleh sebesar 0,282. Hal ini berarti bahwa 28,2 persen kinerja manajerial dapat dijelaskan oleh partisipasi anggaran, sedangkan 71,8 persennya dijelaskan oleh faktor-faktor lain diluar penelitian ini.

\section{Pengujian Hipotesis Kedua}

Pengujian secara parsial terhadap variabel interaksi $\mathrm{X} 1{ }^{*} \mathrm{X} 2$ diperoleh nilai $\mathrm{t}$ hitung sebesar 3,167 dengan signifikansi 0,002. Hal ini berarti, bahwa motivasi yang semakin tinggi akan meningkatkan pengaruh partisipasi anggaran terhadap kinerja manajerial, dengan demikian Hipotesis kedua diterima. Nilai koefisien determinasi adjusted $R$ square menunjukkan sebesar 0,429 yang berarti bahwa 42,9 persen kinerja manajerial dapat diprediksikan oleh partisipasi anggaran, motivasi dan interaksi antara partisipasi anggaran dan motivasi. Sedangkan 57,1 persennya dijelaskan oleh faktor-faktor lain diluar penelitian ini.

\section{Pengujian Hipotesis Ketiga}

Pengujian secara parsial terhadap variabel interaksi $X 1{ }^{*} X 3$ diperoleh nilai t hitung sebesar 2,119 dengan signifikansi 0,038. Artinya bahwa pelimpahan wewenang yang semakin besar akan meningkatkan pengaruh partisipasi anggaran terhadap kinerja manajerial, dengan demikian Hipotesis ketiga diterima. Nilai koefisien determinasi adjusted $R$ square menunjukkan sebesar 0,410 yang berarti bahwa 41,0 persen kinerja manajerial dapat diprediksikan oleh partisipasi anggaran, pelimpahan wewenang dan interaksi antara partisipasi anggaran dan pelimpahan wewenang. Sedangkan 59 persennya dijelaskan oleh faktor-faktor lain diluar penelitian ini.

Partisipasi dalam penyusunan anggaran mempengaruhi secara langsung kinerja manajerial. Adanya pengaruh yang signifikan ini disebabkan karena peran partisipasi dalam penyusunan anggaran tersebut dapat dikaitkan dengan proses keterlibatan manajer dalam menyusun anggaran serta pelaksanaannya untuk mencapai target tertentu. Dengan diberi keterlibatan dalam penyusunan anggaran, maka manajer secara langsung juga dihadapkan pada konsekuensi mereka dalam menetapkan posisi anggaran sebagaimana diangarkan. Tanggung jawab tersebut membawa manajer untuk berusaha memenuhi target anggaran. Hal ini akan memungkinkan manajer bekerja secara lebih baik yang pada akhirnya akan meningkatkan kinerjanya.

Pengujian dengan variabel motivasi sebagai variabel moderating dalam hubungan antara partisipasi anggaran dan kinerja menunjukkan bukti bahwa motivasi mampu memoderasi secara signifikan atas pengaruh partisipasi angaran terhadap kinerja manajerial. Hasil penelitian ini konsisten dengan penelitian Marani dan Supomo (2003) yang menunjukkan secara signifikan motivasi mampu bertindak sebagai variabel moderating di dalam hubungan antara partisipasi penyusunan anggaran dengan kinerja manajerial, sedangkan hasil pengujian ini tidak mendukung penelitian yang dilakukan oleh Riyadi (2000), Wijayanti dan Solichatun 
(2005) yang menyimpulkan bahwa motivasi para manajer tidak mempengaruhi hubungan antara partisipasi penyusunan anggaran dengan kinerja manajerial.

Konsep variabel pelimpahan wewenang sebagai variabel moderating dalam hubungan antara partisipasi anggaran dan kinerja menunjukkan bukti bahwa pelimpahan wewenang mampu memoderasi secara signifikan atas pengaruh partisipasi angaran terhadap kinerja manajerial. Hal ini berarti bahwa manajer yang diberi wewenang yang lebih besar, maka pengaruh partisipasi mereka dalam penyusunan anggaran akan semakin besar terhadap kinerja. Hasil ini mendukung penelitian Marani dan Supomo (2003) dan Slamet Riyadi (2000), yang menunjukkan secara signifikan pelimpahan wewenang mampu bertindak sebagai variabel moderating di dalam hubungan antara partisipasi penyusunan anggaran dengan kinerja manajerial.

\section{SIMPULAN}

Kesimpulan penelitian ini adalah pertama, partisipasi dalam penyusunan anggaran mempengaruhi secara langsung kinerja manajerial. Kedua, variabel pelimpahan wewenang sebagai variabel moderating dalam hubungan antara partisipasi anggaran dan kinerja menunjukkan bukti bahwa pelimpahan wewenang mampu memoderasi secara signifikan atas pengaruh partisipasi angaran terhadap kinerja manajerial. Ketiga, motivasi mampu memoderasi secara signifikan atas pengaruh partisipasi angaran terhadap kinerja manajerial variabel pelimpahan wewenang sebagai variabel moderating dalam hubungan antara partisipasi anggaran dan kinerja menunjukkan bukti bahwa pelimpahan wewenang mampu memoderasi secara signifikan atas pengaruh partisipasi angaran terhadap kinerja manajerial

\section{Saran}

Sampel yang digunakan dalam penelitian ini hanya berasal dari perusahaan manufaktur saja. Bagi peneliti berikutnya sebaiknya dapat diarahkan tidak hanya pada perusahaan manufaktur saja tetapi juga pada perusahaan non manufaktur. Keterbatasan jumlah sampel dalam penelitian ini yang hanya 62 (enam puluh dua) kuesioner dapat melemahkan hasil penelitian ini, sehingga kesimpulan hasil pengolahan data tersebut kurang optimal. Bagi peneliti berikutnya diharapkan dapat menambah jumlah kuesioner menjadi lebih banyak dari apa yang sebelumnya, sehingga diharapkan dapat menarik kesimpulan hasil pengolahan data yang lebih optimal.

\section{DAFTAR REFERENSI}

Anis Chariris dan Imam Ghozali. 2003. Teori Akuntansi. Edisi Revisi. Badan Penerbit Universitas Diponegoro. Semarang.

Anwar Prabu Mangkunegara dan Pri. 2001. Manajemen Sumber Daya Manusia Perusahaan. PT. Remaja Rosdakarya. Bandung.

Bambang Supomo dan Nur Indriantoro. 1998. Pengaruh Struktur dan Kultur Organisasional Terhadap Keefektifan Anggaran Partisiatif dalam Peningkatan Kinerja Manajerial: Studi Empiris Pada Perusahaan 
Manufaktur Indonesia. Kelola. No.18/VII: 61-79.

Fuad Mas'ud. 2002. Manajemen Sumber Daya Manusia. Badan Penerbit Universitas Diponegoro. Semarang. Gunawan Adisaputro dan Marwan Asri. 1998. Anggaran Perusahaan. BPFE. Yogyakarta.

Husein Umar. 1998. Riset Sumber Daya Manusia dalam Organisasi. PT. Gramedia Pustaka Utama. Jakarta.

Imam Ghozali. 2005. Aplikasi Analisis Multivariate Dengan Program SPSS. Badan penerbit Universitas Diponegoro. Semarang.

Hani Hadoko. 1995. Manusia Manajemen Personalia dan Sumber Daya. Liberty. Yogyakarta.

Binti dan Suryanto. 2002. Pengaruh Komitmen Organisasi dan Pelimpahan Wewenang Terhadap Hubungan

Antara Anggaran Partisipatif dan Kinerja Manajerial: Studi Empiris Pada Perusahaan Daerah di Palangkaraya. Media Ekonomi dan Bisnis. Vol. XIV No.2 Desember: 126-137.

Malayu Hasibuan. 1996. Manajemen Sumber Daya Manusia. Penerbit Bumi Aksara. Jakarta.

Marani dan Supomo. 2003. Motivasi dan Pelimpahan Wewenang Sebagai Variabel Moderating Dalam Hubungan

Antara Partisipasi Penyusunan Anggaran Dengan Kinerja Manjerial (Studi Empiris Pada Perguruan

Tinggi Swasta Di Jayapura). Jurnal Maksi. Vol. 2. Januari: 46-62.

Mulyadi. 2001. Sistem Perencanaan dan Pengendalian Manajemen. Edisi II. Penerbit Salemba Empat. Jakarta. Munandar. 2001. Budgeting Perencanaan Kerja. Pengkoordinasian Kerja dan Pengawasan Kerja. BPFE. Yogyakarta.

Nafarin. 2004. Penganggaran Perusahaan. Edisi Revisi. Penerbit Salemba Empat. Jakarta.

Riyadi. 2000. Motivasi dan Pelimpahan Wewenang Sebagai Variabel Moderating dalam Hubungan Antara Partisipasi Penyusunan Anggaran dan Kinerja Manajerial. Jurnal Riset Akuntansi Indonesia. Vol.3 No.2 Juli: 134-150.

Suryo Pratolo. 2003. Pengaruh Struktur Organisasi dan Locus of Control Pada Hubungan Antara Partisipasi Pembuatan Anggaran dan Kinerja Manajerial: Kasus Pada Perguruan Tinggi di DIY. Utilitas. Vol. II No.2 Juli: 15-27.

Vivi Ani Susanti. 2004. Analisis Partisipasi Penyusunan Anggaran Terhadap Kinerja Manajerial: Komitmen Organisasi Sebagai Variabel Moderator: Studi Empiris Pada Perusahaan Manufaktur Go Public yang Terdaftar di BEJ, Berkantor Pusat di Jawa Timur. Jurnal Widya Manajemen dan Akuntansi. Vol.4 No.3 Desember: 264-285.

Wijayanti dan Solichatun. 2005. Pengaruh Motivasi Terhadap Hubungan Antara Partisipasi Dalam Penyusunan Anggaran Dengan Kinerja Manajerial. Studi Kasus Pada PT. Angkasa Pura I. Telaah Bisnis. Volume 6 No. 2 Desember: 179-199. 
Lampiran

Gambar 1

Model Hubungan Partisipasi Anggaran terhadap Kinerja Manajerial

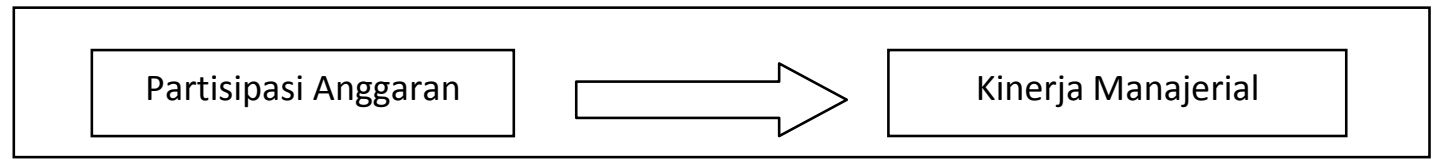

Gambar 2

Model Hubungan Partisipasi Anggaran terhadap Kinerja Manajerial dengan Variabel Moderating Motivasi Kerja

Partisipasi Anggaran

Gambar 3

Model Hubungan Partisipasi Anggaran terhadap Kinerja Manajerial dengan Variabel Moderating Pelimpahan Wewenang

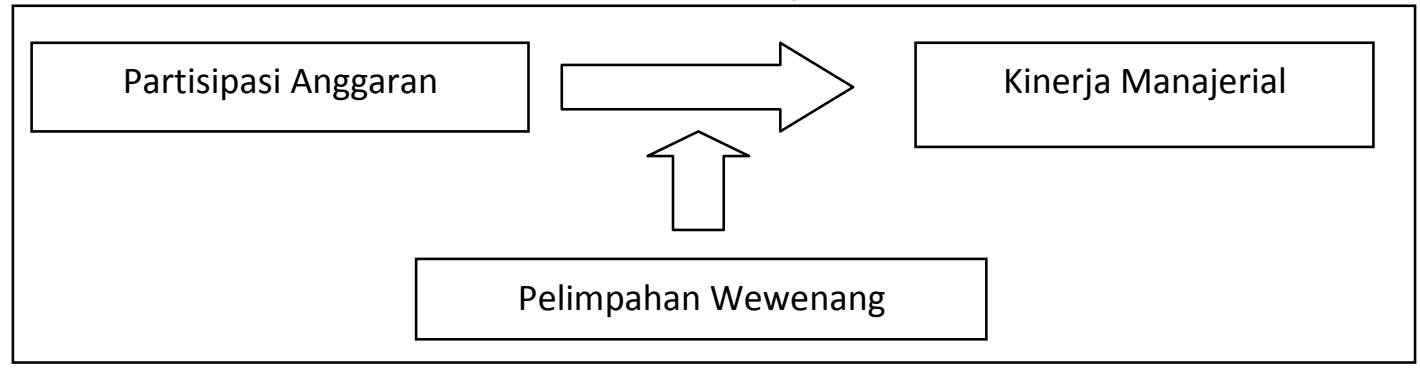

Tabel 1

Sampel Penelitian

\begin{tabular}{|l|l|c|c|c|c|c|}
\hline No. & \multicolumn{1}{|c|}{ Nama Perusahaan } & \multicolumn{4}{c|}{ Jumlah Kuesioner } \\
\hline & & Dikirim & Kembali & Tdk Kembali & Rusak & Layak \\
\hline 1 & PT. SAI APPAREL INDUSTRIES & 15 & 15 & 0 & 3 & 12 \\
\hline 2 & PT. NYONYA MENEER INDONESIA & 15 & 13 & 2 & 2 & 11 \\
\hline 3 & PT. GOLDEN MANYARAN & 15 & 15 & 0 & 4 & 11 \\
\hline 4 & CV. ANEKA ILMU & 15 & 14 & 1 & 4 & 10 \\
\hline 5 & MUCHA ART PRODUCTION & 15 & 10 & 5 & 5 & 5 \\
\hline 6 & PT. ARISAMANDIRI PRATAMA & 15 & 15 & 0 & 2 & 13 \\
\hline & & 90 & 82 & 8 & 20 & 62 \\
\hline
\end{tabular}

Sumber: Data primer, tahun 2008

8 Jurnal Akuntansi Indonesia


Tabel 2

Pengujian Hipotesis Pertama

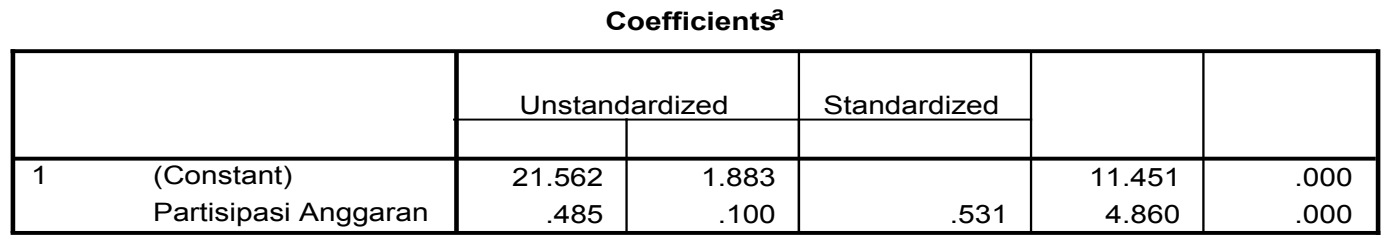

Tabel 3

Koefisien determinasi model pertama

Model Summary

\begin{tabular}{|l|r|r|r|r|}
\hline & & & Adjusted & Std. Error of \\
\hline 1 & $.531^{\mathrm{a}}$ & .282 & .270 & 4.107 \\
\hline
\end{tabular}

Tabel 4

Pengujian Hipotesis Kedua

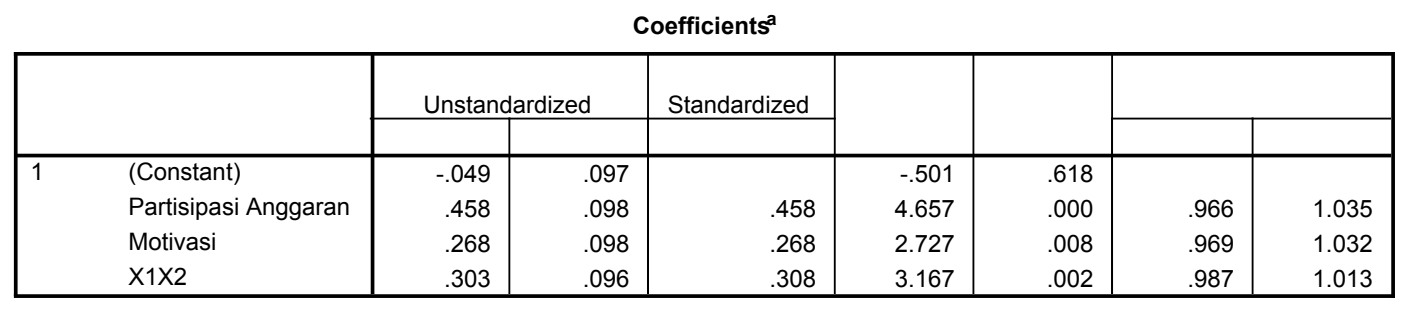

Tabel 5

Koefisien determinasi model kedua

\begin{tabular}{|l|r|r|r|r|}
\multicolumn{5}{|c|}{ Model Summary $^{\text {b }}$} \\
\hline & & & Adjusted & Std. Error of \\
\hline 1 & $.676^{\mathrm{a}}$ & .457 & .429 & .75562067 \\
\hline
\end{tabular}

Tabel 6

Pengujian Hipotesis Ketiga

\begin{tabular}{|c|c|c|c|c|c|c|c|c|}
\hline \multicolumn{9}{|c|}{ Coefficients $^{a}$} \\
\hline & & \multicolumn{2}{|c|}{ Unstandardized } & Standardized & & & & \\
\hline 1 & (Constant) & -.084 & .105 & & -.795 & .430 & & \\
\hline & Partisipasi Anggaran & .418 & .107 & .418 & 3.906 & .000 & .843 & 1.186 \\
\hline & Pelimpahan Wewenang & .354 & .106 & .354 & 3.329 & .002 & .853 & 1.173 \\
\hline
\end{tabular}

PENGARUH MOTIVASI DAN PELIMPAHAN WEWENANG SEBAGAI VARIABEL MODERATING DALAM HUBUNGAN ANTARA PARTISIPASI ANGGARAN DAN KINERJA MANAJERIAL Studi Empiris Pada Beberapa Perusahaan Manufaktur di Semarang 
Tabel 7

Koefisien determinasi model ketiga

Model Summary

\begin{tabular}{|l|r|r|r|r|}
\hline & & & Adjusted & Std. Error of \\
\hline 1 & $.663^{a}$ & .439 & .410 & .76781383 \\
\hline
\end{tabular}

Jurnal Akuntansi Indonesia 